\title{
Bioleaching of trace metals from coal ash using local isolate from coal ash ponds
}

\author{
Denvert Pangayao ${ }^{1,2,}$, Susan Gallardo ${ }^{2}$, Michael Angelo Promentilla ${ }^{2}$, and Eric van Hullebusch ${ }^{3}$ \\ ${ }^{1}$ Chemical Engineering Department, Pamantasan ng Lungsod ng Maynila, Manila, Philippines \\ ${ }^{2}$ Chemical Engineering Department, De La Salle University, Manila, Philippines \\ ${ }^{3}$ Department of Environmental Engineering and Water Technology, UNESCO-IHE Institute for Water Education, Delft, The Netherlands
}

\begin{abstract}
Bioleaching of chromium, copper, manganese and zinc from coal ash were investigated using isolates from coal ash ponds particularly Psuedomonas spp. Six (6) different coal ash ponds were examined however, after initial screening Psuedomonas spp. were only present in three (3) coal ash ponds. Among the three coal ash ponds, results showed that eight (8) putative Pseudomonas spp. isolates were present that were identified using the Polymerase Chain Reaction (PCR). Using the eight putative Pseudomonas spp. for bioleaching at optimum conditions and 15 days, the $\mathrm{pH}$ value ranges from 8.26 to 8.84 which was basic in nature. Moreover, the maximum metal leached were $8.04 \% \mathrm{Cr}, 12.05 \% \mathrm{Cu}, 4.34 \% \mathrm{Mn}$ and $10.63 \% \mathrm{Zn}$.
\end{abstract}

\section{Introduction}

Coal is the most widely used and cheap source of fossil resource on earth. The global consumption of coal has increased from 4.92 billion tons in 2002 to 7.43 billion tons in 2012. Coal has been used as a solid fuel to produce heat and electricity via combustion in power plants [1-3]. Upon combustion of coal, $80 \%$ is composed of fly ash and $20 \%$ is composed of bottom ash. In a global perspective, 40 to $45 \%$ of the electric power generated came from thermos power plants amounting to 600 million tons of coal ash are produce annually [2-4]

As of 2016, Philippine's coal consumption is 20.296 million metric tons [5] and more than $47 \%$ of the Philippine's power generation came from coal [6]. With the rapid increase in power demand, high quantities of coal ash are being discharge daily. Majority of the coal ash are being disposed in ash ponds and lagoons that can pose environmental and health risks [4, 7-9]. Due to massive amount of coal ash generated, it is considered as secondary material for different applications such as brick production, mine filling, drainage media, replacement for conventional soil and gravel for road side embankment, road construction, structural fill and various cement-based composites including concrete and mortar [10-12].

In the recent years, green technologies are significant in addressing issues on environmental pollution such as biological leaching or bioleaching $[10,13]$. Bioleaching is an ecological friendly process of using microorganism to extract soluble material from secondary resources via the production of organic or inorganic acids [13-15].

This research used indigenous microorganism from coal ash pond particularly Pseudomonas spp. Pseudomonas spp. is the second most used bioleaching microorganism due to its production of organic acid such as gluconic, oxalic and citric acid [16-17].

The main objective of this research to determine the maximum percent metal leached from coal ash using an indigenous microorganism from coal ash pond under optimum conditions. Moreover, the identified microorganism was Pseudomonas spp., heterotrophic bacterium that produces organic acid. The metals under investigation are chromium, copper, manganese and zinc

\section{Materials And Methods}

\subsection{Coal ash from coal ash pond}

A mixture of fly and bottom ash was used in the experiment collected from the ash pond. The coal ash was provided by the private coal fired power plant that uses local and imported coal. Moreover, the power plant uses Circulating Fluidized Bed (CFB) Boiler. The coal ash was dried at $105^{\circ} \mathrm{C}$ for 24 hours, then sieved passing through particle size 0.075 microns (\#200 mesh). The particle size was constant throughout the experiment. The ash is alkali in nature with $\mathrm{pH}$ of $10-11.5$.

\subsection{Determination of Microbial Population and Isolation of the Microorganism from Coal Ash Pond}

\subsubsection{Coal Ash sample from the Philippines}

The ash samples were collected from the different coal power plant in the Philippines namely: PP1 from the partner power plant, PP 2 and PP3 from Central Luzon, PP 4 and PP 5 from Southern Luzon and PP 6 from Visayas. All samples were collected from the oldest part

Corresponding author: dcpangayao@plm.edu.ph 
of the ash pond, one (1) meter below. And stored in a sterile container.

The screening and identification of the microbial population was performed by the Microbiology Department of University of the Philippines - Los Baños (UPLB). Moreover, the

Also, the preservation of the isolated microorganism was done through lyophilization by UPLB National Institute of Molecular Biology and Biotechnology.

\subsubsection{Determination of the Microbial Population of the Coal Ash}

The initial screening of total heterotrophic bacteria, yeast and molds and detection of Pseudomonas spp. was conducted. Initially all coal ash samples were basic in nature with a $\mathrm{pH}$ value of 9 to 11 . The following procedures were done: (1) heterotrophic bacterial count: plate count agar with 1,000 units/ml nystatin; (2) molds and yeast count: potato dextrose agar with $100 \mathrm{ppm}$ streptomycin and $50 \mathrm{ppm}$ rose bengal, adjusted to $\mathrm{pH} 9.0$ with $5.0 \mathrm{M} \mathrm{NaOH}$ and (3) detection of Pseudomonas spp. using most probable number (MPN) method on Arginine broth. Heterotrophic bacteria and Pseudomonas spp. were counted after 3 days of incubation while yeast and molds were counted after 5 days.

\subsubsection{Isolation and Purification of the Microorganism}

Based on literature, Pseudomonas spp. is the widely used heterotrophic bacteria for bioleaching. This microorganism was isolated in the coal ash samples. The isolated Pseudomonas spp. were preserved using lyophilization at UPLB National Institute of Molecular Biology and Biotechnology.

\subsection{Polymerase Chain Reaction (PCR) amplification of DNA and DNA Sequencing}

The identification of the specific Pseudomonas specie was done using TaKaRa PCR thermal Cycler Dice TP600 at the Nakasaki Laboratory of Tokyo Institute of Technology (Japan). The extracted DNAs were amplified using the primers 16SF (5'AGAGTTTGATCCTGGCTCAGGA3') and 16SR (5'GGTTACCTTGTTACG3'). The detected genome sequence was matched using Basic Location Alignment Search Tool (BLAST) database provided by the National Center of Biotechnology and Information (NCBI).

\subsection{Bioleaching Experiment}

\subsubsection{Reviving the Pseudomonas spp}

The ampules of the lyophilized Pseudomonas spp were opened using a metal file. Then, $1 \mathrm{ml}$ of sterile water was added to the ampule and was swirled and gently tapped for 5 to 10 seconds. The liquid was transferred in a $100 \mathrm{ml}$ fresh nutrient broth media. The Pseudomonas spp was incubated at $37^{\circ} \mathrm{C}$ at $90 \mathrm{rpm}$ for 7 days [18-20].

\subsubsection{Growth of Pseudomonas spp}

The incubated Pseudomonas spp were streaked in a nutrient agar plates. The nutrient agar plates were placed in an incubator at $37^{\circ} \mathrm{C}$ for 3 days. After which, one colony was place in an inoculating looped then transferred to $100 \mathrm{ml}$ fresh nutrient broth media. Pseudomonas spp. was cultured in a Nutrient broth medium containing of $1 \mathrm{~g} / \mathrm{L}$ yeast, $2 \mathrm{~g} / \mathrm{L}$ peptone and 5 $\mathrm{g} / \mathrm{L}$ glucose. 8 grams of nutrient broth medium was dissolved in 1 liter of deionized water. The solution was autoclaved at $121^{\circ} \mathrm{C}$ for 15 minutes [21]. The resulting solution has a $\mathrm{pH}$ of 7.2. Then the inoculum was placed in a water bath shaker (Visio VS-1205SW1) at $90 \mathrm{rpm}$ and $37^{\circ} \mathrm{C}$. Pseudomonas spp were incubated for 5 days prior to bioleaching [18-20].

\subsection{Bioleaching experiment using Pseudomonas spp}

The bioleaching experiments were conducted in a 250 $\mathrm{mL}$ Erlenmeyer flask with the following conditions: $1 \%$ pulp density ( $1 \mathrm{~g}$ of ash per $100 \mathrm{ml}$ medium), $90 \mathrm{rpm}$ and $37^{\circ} \mathrm{C}$. The solution were autoclaved at $121^{\circ} \mathrm{C}$ for 15 minutes and cooled. $5 \mathrm{ml}$ of the inoculum was placed in a $100 \mathrm{ml}$ fresh medium with the ash. The bioleaching experiment was for 15 days [22]. The extracted solution was filtered using a 0.45 micrometer cellulous acetate filter.

\subsection{Analytical Methods}

X-ray Diffraction (XRD) analysis was performed using Bruker D8 Advance diffractometer equipped with copper radiation Sol-X detector $(\mathrm{CuK} \alpha, \lambda=0.15406 \mathrm{~nm})$. The data were recorded with a $1 \mathrm{~s}$ step time and $0.02^{\circ}$ scan step between $2^{\circ}$ to $80^{\circ}$. On the other hand, X-ray Fluorescence (XRF) analysis was conducted using Pananalytical Xflourescence spectrometer equipped with $150 \mathrm{eV}(\mathrm{Mn} \mathrm{Ka})$ resolution Energy Dispersive Minipal 4 tube (Rh X Ray tube $-30 \mathrm{kV}-9 \mathrm{~W})$. All samples were dried at room temperature.

Also, metal analysis was done using Shimadzu AA6300 AAS analysis. Different wavelength were used namely: $267 \mathrm{~nm}$ for $\mathrm{Cr}, 324 \mathrm{~nm}$ for $\mathrm{Cu}, 257 \mathrm{~nm}$ for $\mathrm{Mn}$ and $213 \mathrm{~nm}$ for $\mathrm{Zn}$ were used to detect the concentration of the trace metals in the solution, reported as $\mathrm{mg} / \mathrm{kg}$ or ppm. To preserve the sample, few drops of concentrated nitric acid was added.

\section{Results and Discussion}

\subsection{Mineralogical composition: XRD}

Fig. 1 shows the mineral composition of the coal ash namely: quartz- $\mathrm{SiO}_{2}$, lime- $\mathrm{CaO}$, anhydrite, tricalcium aluminate, periclase, melilite, mullite and rutile. These 
minerals were also identified by the different researchers [23-29].

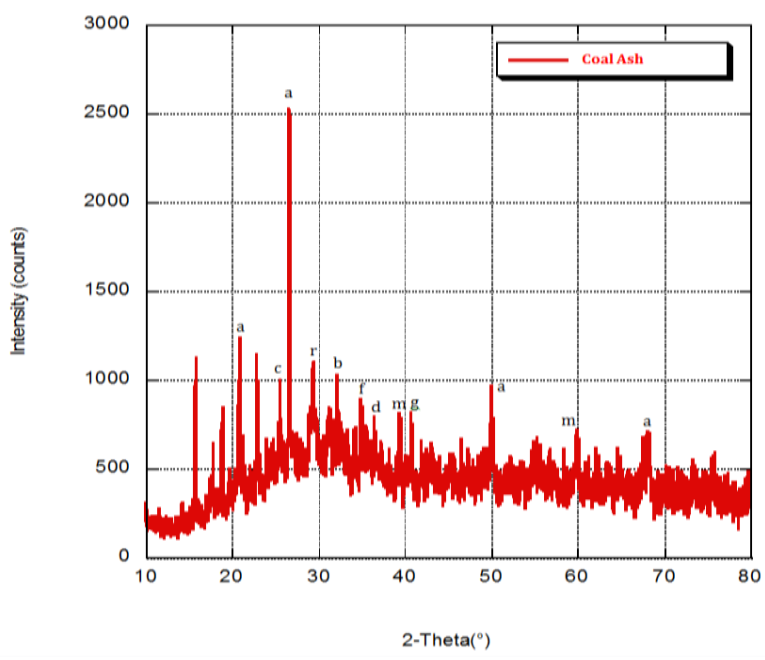

Fig. 1. XRD Analysis for Coal Ash (a: Quartz-SiO2, b: Melilite, c: Anhydrite, d: Tricalcium aluminate, f: Lime-CaO, g: Periclase, m: Mullite, r: Rutile).

\subsection{Elemental Composition: XRF}

The chemical analyses of the ash samples were performed to determine the composition of the material. Table 1 shows the major and trace elemental composition.

Table 1. XRF analysis of ash samples.

\begin{tabular}{|l|c|}
\hline \multicolumn{1}{|c|}{ Element } & \% by weight \\
\hline Calcium & 39.46 \\
\hline Silicon & 25.70 \\
\hline Aluminum & 10.62 \\
\hline Iron & 6.20 \\
\hline Sulfur & 5.98 \\
\hline Sodium & 3.99 \\
\hline Chlorine & 2.11 \\
\hline Potassium & 1.83 \\
\hline Magnesium & 1.67 \\
\hline Titanium & 1.51 \\
\hline Strontium & 0.43 \\
\hline Barium & 0.22 \\
\hline Zirconium & 0.05 \\
\hline Tin & 0.035 \\
\hline Vanadium & 0.034 \\
\hline Chromium & 0.033 \\
\hline Nickel & 0.025 \\
\hline Manganese & 0.023 \\
\hline Tellurium & 0.021 \\
\hline Copper & 0.020 \\
\hline Zinc & 0.011 \\
\hline Bromine & 0.011 \\
\hline Yttrium & 0.007 \\
\hline
\end{tabular}

The highest element is calcium which may be originated on the limestone that was being added during the combustion process $[24,28,30]$. The minerals identified by XRD coincide with the chemical results of the main composition obtained by XRF analysis (Table
2). Moreover, the total metal contents in the ash are 0.96 $\mathrm{mg} / \mathrm{kg} \mathrm{Zn}, 4.13 \mathrm{mg} / \mathrm{kg} \mathrm{Mn}, 0.81 \mathrm{mg} / \mathrm{kg} \mathrm{Cr}$ and 2.22 $\mathrm{mg} / \mathrm{kg} \mathrm{Cu}$.

\subsection{Microbial Population Determination in Coal Ash Samples}

Microbial populations were analyzed to identify the possible microorganism that can be used for bioleaching of coal ash. Microbial count was determined by Microbiology Department of UPLB. Based on literature, other than Acidithiobacillus spp., Pseudomonas spp. was considered as a possible microorganism for bioleaching [31-35]. Table 2 shows bacterial and molds count and putative Pseudomonas spp. present in the coal ash sample.

Table 2. Microbial Count Summary

\begin{tabular}{|l|c|c|c|c|}
\hline $\begin{array}{c}\text { Power } \\
\text { Plant }\end{array}$ & Bacteria & Molds & $\begin{array}{c}\text { Putative } \\
\text { Pseudomonas } \\
\text { species }\end{array}$ & $\begin{array}{c}\text { Number of } \\
\text { Pseudomonas } \\
\text { isolate }\end{array}$ \\
\hline PP 1 & $\begin{array}{c}<2500 \\
\mathrm{cfu} / \mathrm{g}\end{array}$ & ---- & $<1 \mathrm{MPN} / \mathrm{g}$ & No isolate \\
\hline PP 2 & $\begin{array}{c}3.0 \times 10^{4} \\
\mathrm{cfu} / \mathrm{g}\end{array}$ & $\begin{array}{c}2.0 \times 10^{4} \\
\mathrm{cfu} / \mathrm{g}\end{array}$ & $<1 \mathrm{MPN} / \mathrm{g}$ & No isolate \\
\hline PP 3 & $\begin{array}{c}4.9 \times 10^{5} \\
\mathrm{cfu} / \mathrm{g}\end{array}$ & $\begin{array}{c}3.3 \times 10^{3} \\
\mathrm{cfu} / \mathrm{g}\end{array}$ & $233 \mathrm{MPN} / \mathrm{g}$ & 4 isolate \\
\hline PP 4 & $\begin{array}{c}4.9 \times 10^{6} \\
\mathrm{cfu} / \mathrm{g}\end{array}$ & $\begin{array}{c}1.3 \times 10^{5} \\
\mathrm{cfu} / \mathrm{g}\end{array}$ & $33 \mathrm{MPN} / \mathrm{g}$ & 4 isolate \\
\hline PP 5 & $\begin{array}{c}2.2 \times 10^{3} \\
\mathrm{cfu} / \mathrm{g}\end{array}$ & $\begin{array}{c}2.4 \times 10^{4} \\
\mathrm{cfu} / \mathrm{g}\end{array}$ & $<1 \mathrm{MPN} / \mathrm{g}$ & No isolate \\
\hline PP 6 & $\begin{array}{c}2.1 \times 10^{5} \\
\mathrm{cfu} / \mathrm{g}\end{array}$ & $\begin{array}{c}4.5 \times 10^{2} \\
\mathrm{cfu} / \mathrm{g}\end{array}$ & $4 \mathrm{MPN} / \mathrm{g}$ & 1 isolate \\
\hline
\end{tabular}

cfu: colony forming unit; MPN: Most Probable Number

Table 2 shows that 9 possible Pseudomonas spp. isolate were identified. There are 4 isolates from PP 3 and PP4 and 1 isolate from PP 6. On the other hand, no isolate were detected on PP 1, PP 2 and PP 5.

Table 3. PCR result of Pseudomonas spp

\begin{tabular}{|c|c|}
\hline Samples & Most closely related species (Identity: $\mathbf{1 0 0 \%})$ \\
\hline PP 3-1 & $\begin{array}{l}\text { P. aeruginosa, } P \text {. alcaligenes, } P \text {. citronellolis, } P \text {. } \\
\text { delhiensis, } P \text {. denitrificans, } P \text {. guezennei, } P \text {. knackmussii, } \\
P . \text { multiresinivorans, } P \text {. nitroreducens, } P \text {. resinovorans, } P \text {. } \\
\text { stutzeri }\end{array}$ \\
\hline PP 3-2 & $\begin{array}{l}\text { P. putida, } P . \text { indoloxydans, } P . \text { plecoglossicida, } P . \\
\text { pseudoalcaligenes }\end{array}$ \\
\hline PP 3-3 & $\begin{array}{l}\text { P. aeruginosa, } P . \text { alcaligenes, } P \text {. citronellolis, } P . \\
\text { denitrificans, } P . \text { knackmussii, } P \text {. resinovorans, } P \text {. stutzeri }\end{array}$ \\
\hline PP 6- 1 & $\begin{array}{l}\text { P. aeruginosa, } P \text {. alcaligenes, } P \text {. citronellolis, } P \text {. } \\
\text { delhiensis, } P . \text { denitrificans, } P \text {. guezennei, } P \text {. knackmussii, } \\
P . \text { multiresinivorans, } P \text {. nitroreducens, } P \text {. resinovorans, } P \text {. } \\
\text { stutzeri }\end{array}$ \\
\hline PP 4-1 & $\begin{array}{l}\text { P. aeruginosa, } P . \text { putida, } P . \text { alcaligenes, } P . \\
\text { brassicacearum, } P \text {. denitrificans, } P . \text { entomophila, } \\
\text { P.monteilii, } P . \text { helmanticensis, P.knackmussii, P. lini, } P . \\
\text { poae, , P. resinovorans, } \\
P . \text { stutzeri, Azotobacter vinelandii }\end{array}$ \\
\hline PP 4-2 & $\begin{array}{l}\text { P. aeruginosa, } P . \text { alcaligenes, } P \text {. citronellolis, } P . \\
\text { delhiensis, } P \text {. denitrificans, } P \text {. guezennei, } P . \text { knackmussii, } \\
P . \text { multiresinivorans, } P . \text { nitroreducens, } P \text {. resinovorans, } P \text {. } \\
\text { stutzeri }\end{array}$ \\
\hline PP 4-3 & $\begin{array}{l}\text { P. aeruginosa, } P . \text { alcaligenes, } P . \text { citronellolis, } P . \\
\text { delhiensis, } P \text {. denitrificans, } P . \text { guezennei, } P . \text { knackmussii, } \\
P . \text { multiresinivorans, } P . \text { nitroreducens, } \\
P . \text { resinovorans, } P \text {. stutzeri }\end{array}$ \\
\hline PP 4-4 & $\begin{array}{l}\text { P. aeruginosa, } P . \text { alcaligenes, } P \text {. citronellolis, } P . \\
\text { delhiensis, } P \text {. denitrificans, } P \text {. guezennei, } P . \text { knackmussii, } \\
P . \text { multiresinivorans, } P . \text { nitroreducens, } \\
P . \text { resinovorans, } P \text {. stutzeri }\end{array}$ \\
\hline
\end{tabular}


Pseudomonas spp. were identified using Polymerase Chain Reaction (PCR). Table 3 shows the putative Pseudomonas spp. present in the different coal ash.

According to the PCR result, putative Pseudomonas spp. isolates are the same for PP 3-1, PP 3-3, PP 4-2 to PP 4-4 and PP 6-1. However, PP 3-2 and PP 4-1 has a different consortium of Pseudomonas spp. Pseudomonas aeruginosa is present in 7 samples (PP 3-1, PP 3-3, PP 4-1 to PP 4-4 and PP 6-1) while Pseudomonas putida is only present in PP 3-3. In previous researches, these microorganisms were used in bioleaching for extracting metals from secondary resources. These different Pseudomonas spp. isolate were used in the bioleaching coal ash. Figure 2 shows the streak plate of the 8 isolate samples.

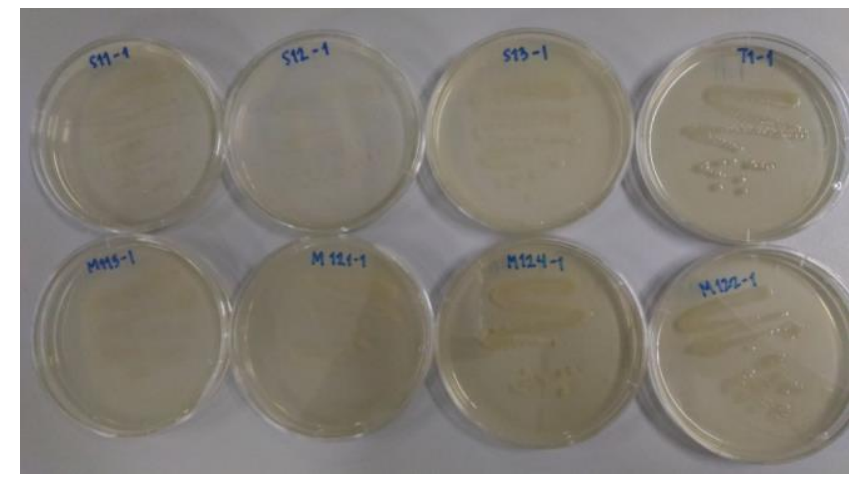

Fig. 2. Different Pseudomonas spp isolates (From L to R and T to B: PP 3-1, PP 3-2, PP 3-3, PP 6-1, PP 4-1 to PP 4-4)

\subsection{Bioleaching using Pseudomonas spp.}

After 15 days of bioleaching experiment, Table 4 shows the percent metal leached for chromium, copper, manganese and zinc for each Pseudomonas spp. isolates. Moreover, Figure 3 illustrate the different $\mathrm{pH}$ profile for the different Pseudomonas spp. isolates.

Table 4. \% Metal Leached using Pseudomonas spp isolates

\begin{tabular}{|c|c|c|c|c|}
\hline Isolate & \% Zn & \% Cr & \% Mn & \% Cu \\
\hline PP 3-1 & $\mathbf{1 0 . 6 3}$ & 7.52 & $\mathbf{4 . 3 4}$ & 10.10 \\
\hline PP 3-2 & 10.39 & $\mathbf{8 . 0 4}$ & 2.75 & $\mathbf{1 2 . 0 5}$ \\
\hline PP 3-3 & 9.19 & 8.03 & 3.90 & 8.87 \\
\hline PP 6-1 & 9.61 & 5.83 & 3.19 & 9.47 \\
\hline PP 4-1 & 9.03 & 5.99 & 2.35 & 9.38 \\
\hline PP 4-2 & 8.34 & 7.27 & 4.14 & 8.98 \\
\hline PP 4-3 & 10.41 & 6.63 & 3.70 & 10.24 \\
\hline PP 4-4 & 9.52 & 7.90 & 3.94 & 11.09 \\
\hline
\end{tabular}

Table 4 shows that the maximum metal leached for chromium is $8.04 \%$ and copper is $12.05 \%$ from PP $3-2$ and $4.34 \%$ for manganese and $10.63 \%$ for zinc from PP 3-1. Based on the PCR result, PP 3-2 contains Pseudomonas aeruginosa and PP 3-1 contains Pseudomonas putida in the consortium.

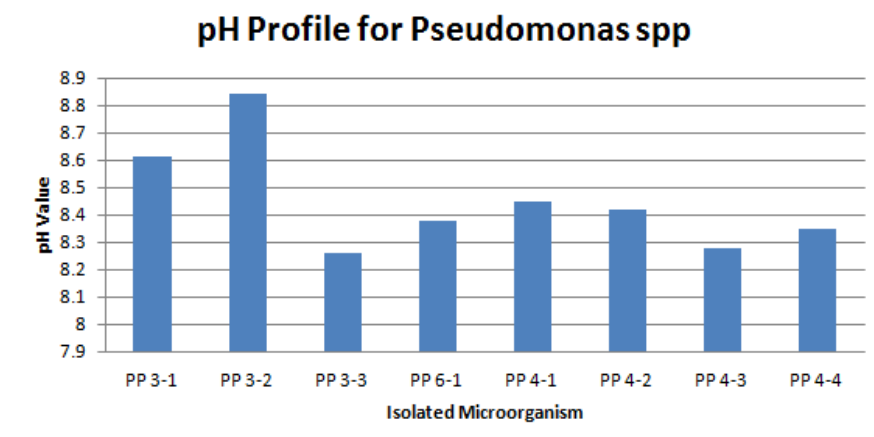

Fig. 3. $\mathrm{pH}$ values against the Pseudomonas spp isolate

Figure 3 shows the $\mathrm{pH}$ values of the Pseudomonas spp. isolate after the bioleaching experiment. The $\mathrm{pH}$ value of the solution ranges from 8.26 to 8.84 which is basic. However, taking into consideration the $\mathrm{pH}$ of the ash which is 11 , the decrease in the $\mathrm{pH}$ value is an indirect indication of possible formation of organic acid such as oxalic, gluconic or citric acid by the Pseudomonas spp. [18-19, 35-36]

Based on literature, bioleaching using Acidithiobacillus spp. extracted more metal as compared to Pseudomonas spp. The microbial activity of Pseudomonas spp. is in the circumneutral $\mathrm{pH}$ value of 7.8 , because of this the efficiency of metal extraction is lower compared to low $\mathrm{pH}$ value. It should be noted that metal extraction is favorable under acidic conditions. Most metals like chromium, copper, manganese and zinc favor metal extraction at lower $\mathrm{pH}$. On the other hand, production of extracellular polymeric substance (ESP) enhances metal solubilization using Pseudomonas spp. $[31,37]$.

\section{Conclusion}

Bioleaching of coal ash using Pseudomonas spp. isolate from coal ash pond was investigated. Based on the result, the total metal content of the coal ash are 0.81 $\mathrm{mg} / \mathrm{kg} \mathrm{Cr}, 2.22 \mathrm{mg} / \mathrm{kg} \mathrm{Cu}, 4.13 \mathrm{mg} / \mathrm{kg} \mathrm{Mn}$ and 0.96 $\mathrm{mg} / \mathrm{kg} \mathrm{Zn}$. Moreover, the minerals identified were quartz- $\mathrm{SiO}_{2}$, lime-CaO, tricalcium aluminate and the major elements were calcium, silicon and aluminum. Also, high calcium content results in the alkalinity of the ash sample.

From the initial screening and identification 8 putative Pseudomonas spp. were obtained. PCR result shows that 6 isolate has the same Pseudomonas spp. consortium namely: PP 3-1, PP 3-3, PP 4-2 to PP 4-4 and PP 6-1. On the other hand, PP 3-2 and PP 4-1 have different consortium. Pseudomonas aeruginosa is present in 7 samples namely (PP 3-1, PP 3-3, PP 6-1 and PP 4-1 to PP 4-4) and Pseudomonas putida in PP 4-2.

After 15 days of bioleaching experiment, the maximum metal extracted were $12.05 \% \mathrm{Cu}$ and $8.04 \%$ $\mathrm{Cr}$ from PP $3-2$ isolate and $10.63 \% \mathrm{Zn}$ and $4.34 \% \mathrm{Mn}$ from PP 3-1 isolate 
This research would not be possible without the help of the following institution namely: Engineering Research and Development for Technology (ERDT) - Department of Science and Technology (DOST), Philippines, Campus France, Republic of France, Japan International Cooperation Agency (JICA) Project Office for the ASEAN University Network/Southeast Asia Engineering Education Development Network (AUN/SEED-Net) under the Collaborative Research Program for Common Regional Issues (CRC) with De La Salle University. Furthermore, we would like to thank the partner coal fired power plant, Tokyo Institute of Technology, Tokyo, Japan and Ile de France Region for the ICP-OES analysis.

\section{References}

1. Y. Deng, Z. Zhang, C. Liu, W. Liu, Y. Cui, X. Du, D. Xu, H. Guo, App. Ener., 200 (2017)

2. J. Xu, J. Dai, H. Xie, C. Lv, C., Ener. Pol. 109 (2017)

3. P. A. Strizhak, M. A. Dmitrienko, Sci. of Tot. Env., 598 (2017)

4. W-S. Ahn, Y-R. Lee, J. T. Soe, S. Zhang, J-W. Ahn, M. B. Park, Chem. Eng. J., 317 (2017)

5. www.doe.gov.ph/overall-statistics-on-coal

6. www.doe.gov.ph/philippine-power-statistcs

7. N. Makul, G. Sua-lam, J. of Clean. Prod., 100 (2017)

8. Y-S. Kim, M. T. Do, H-K Kim, G. Kang, Construc. and Build. Mat., 124 (2016)

9. E. Connors, Utilities Pol., 34 (2016)

10. N. Gupta, V. Gedam, C. Moghe, P. Labhasetwar, Env. Tech. and Innov., 7 (2017)

11. H-K. Kim, Construc. and Build. Mat., 91 (2015)

12. M. L. D. Jayaranjan, E. D. van Hullebusch, A. P. Annachhatre, Rev. in Env. Sci. \& Biotech., 13(4) (2014)

13. M. Diao, E. Taran, S. Mahler, A. V. Nguyen, Adv. in Col. and Interface Sci., 212 (2014)

14. J-C. Lee, B. D. Pandey, Wast. Mang., 32 (2012)

15. F. Bakhtiari, H. Atashi, M. Zivdar, S. Seyedbagheri, M. H. Fazaelipoor, J. of Indus. and Eng. Chem., 17 (2011)

16. S. K. Sen, M. M. Das, P. Bandyopadhyah, R. R. Dash, Eco. Eng., 88 (2016)

17. W. A. G. Hassanien, O. A. N. Desouky, S. S. E. Hussein, Walailak J. of Sci. and Tech., 11 (2013)

18. R. Jujun, Z. Xingjion, Q. Yiming, H. Jian, Wast. Mang., 34 (2014)

19. R. Singh, N. R. Bishnoi, A. Kirrolia, R. Kumar, Biores. Tech., 127 (2013)

20. M. I. Husseiny, M. Abd El-aziz, Y. Badr,M. A. Mahmoud, Spectrochim. Act. Part A, 67 (2007)

21. S. K. Sen, M. M. Das, P. Bandyopadhyah, R. R. Dash, Eco. Eng., 88 (2016)

22. S. M. J. Mirazimi, F. Rashchi, $7^{\text {th }}$ Inter. Chem. Eng. Cong. \& Exhib., Kish, Iran, Novmber 21-24, 2011.

23. G. Neupane, R. Donahoe, Fuel, 104 (2013)
24. G. Akar, M. Polat, G. Galecki, U. Ipekoglu, Fuel Process. Tech., 104 (2012)

25. N. Koukouzas, C. Ketikidis, G. Itskos, Fuel Process. Tech., 92 (2011)

26. S. Hareeparsad, L. Tiruta-Barna, C. Brouckaert, C. Buckley, J. of Haz. Mat., 186 (2011)

27. M. Ahmaruzzaman, Prog. in Ener. and Comb. Sci., 36 (2010)

28. G. Skordas, P. Grammelis, M. Prokopidou, E. Kakaras, G. Sakellaropoulos, Fuel, 88 (2009)

29. U. Demir, A. Yamik, S. Kelebek, B. Oteyaka, A. Ucar, O. Sahbaz, Fuel, 87 (2008)

30. B. M. Steenari, S. Schelander, O. Lindqvist, Fuel, 78 (1999)

31. A. Potysz, P. N. L. Lens, J. van de Vossenberg, E. R. Rene, M. Grybos, G. Guibaud, J. Kierczak, E. D. van Hullebusch, Appl. Geochem., 68 (2016)

32. S. M. J. Mirazimi, Z. Abbasalipour, F. Rashchi, J. of Env. Mang., 153 (2015)

33. M. A. Shabani, M. Irannajad, A. R. Azadmehr, M. Meshkini, M. Intern. J. of Min., Metal. and Mat., 20 (2013)

34. V. A. Pham, Y. P. Ting, Adv. Mat. Res., 71-73 (2009).

35. G. Aouad, J-L. Crovisier, V. A. Geoffroy, J-M. Meyer, P. Stille, E. Hutchens, J. Mutterer, Sci. of the Tot. Env., 393 (2008)

36. R. Andreazza, S. Pieniz, L. Wolf, M-K. Lee, F. A. O. Camargo, B. C. Okeke, Sci. of the Tot. Env., 408 (2010)

37. M. Izquierdo, X. Querol, Intern. J. of Coal Geol., 94 (2012) 